\title{
ISOLASI JAMUR ENDOFIT DAN PRODUKSI METABOLIT SEKUNDER ANTIOKSIDAN DARI DAUN PACAR (Lawsonia inermis L.)
}

\author{
Vilca Veronica Hasiani, Islamudin Ahmad, Laode Rijai \\ Laboratorium Penelitian dan Pengembangan FARMAKA TROPIS Fakultas Farmasi \\ Universitas Mulawarman, Samarinda, Kalimantan Timur \\ Email : vhasiani@yahoo.com
}

\begin{abstract}
ABSTRAK
Jamur endofit adalah kelompok jamur yang sebagian atau seluruh hidupnya berada dalam jaringan tumbuhan hidup dan biasanya tidak merugikan pada inangnya. Jamur-jamur endofit umumnya memproduksi metabolit sekunder yang memiliki aktivitas biologis yang bermanfaat seperti misalnya senyawa-senyawa anti kanker, anti virus, atau antibakteri. Jamur endofit dapat ditemukan pada berbagai jenis tumbuhan, terutama pada tumbuhan obat, seperti misalnya Lawsonia inermis, L., salah satu tumbuhan obat yang banyak terdapat di Indonesia. Penelitian ini bertujuan untuk memperoleh isolat jamur endofit dari daun Lawsonia inermis, L., karakterisasi jamur endofit yang diperoleh serta menguji aktivitas antioksidan dari isolat jamur yang diperoleh terhadap DPPH. Dari penelitian yang dilakukan diperoleh 3 isolat jamur endofit dari daun Lawsonia inermis, L,. Ekstrak isolat jamur endofit tersebut memiliki aktivitas antioksidan.
\end{abstract}

Kata kunci : anti-oksidan, jamur endofit, Lawsonia inermis, L

\begin{abstract}
Endophytic fungi is cluster of fungi lives in the plant tissues for a few time or entire of its life. This kind of fungi usually produces secondary metabolites which have significant bioactivity, such as anti cancer, anti virus, antioksidant or antibacterial agents. Endophytic fungi can be isolated from many kinds of plants, especially medicinal plant such as Lawsonia inermis, L. which is abundant in Indonesia. The objective of this research is to isolate endophytic fungi from leaves of Lawsonia inermis, L., characterization profile endophytic fungi and investigate its antioxidant activity towards DPPH with method spray DPPH. From the experiments we could obtain 3 endophytic fungi isolates from leaves of Lawsonia inermis, L, and experiments showed that all of the endophitic fungi have significant antioxidant activity towards DPPH.
\end{abstract}

Keywords: antioxidant, endophytic, fungi, Lawsonia inermis, L.

\section{PENDAHULUAN}

Pencarian sumber senyawa bioaktif terus menerus dilakukan seiring dengan makin banyaknya penyakitpenyakit baru yang bermunculan, mulai dari penyakit infeksi, kanker, dan beberapa penyakit berbahaya lainnya. Senyawa bioaktif dapat diperoleh dari beberapa sumber, diantaranya dari tumbuhan, hewan, mikroba dan organisme laut (Prihatiningtias, 2005). 
Salah satu sumber senyawa bioaktif yang dewasa ini menjadi populer adalah yang berasal dari mikroba. Salah satu mikroba penghasil senyawa bioaktif adalah jamur endofit yang merupakan jamur yang tumbuh dan mengkolonisasi di jaringan tumbuhan (inang) terutama di bagian akar, batang dan daun. Jamur endofit dapat menghasilkan senyawasenyawa bioaktif dan metabolit sekunder yang sama dengan inangnya. Hal ini diduga karena jamur endofit mengalami koevolusi transfer genetik dari inangnya. Kemampuan mikroba endofit dalam menghasilkan senyawa bioaktif merupakan hal yang sangat potensial untuk dikembangkan menjadi obat herbal. Hal ini karena mikroba endofit merupakan mikroorganisme yang mudah ditumbuhkan, memiliki siklus hidup yang pendek dan dapat menghasilkan jumlah senyawa bioaktif dalam jumlah besar dengan metode fermentasi.

Salah satu tanaman obat yang dapat digunakan sebagai sumber isolat jamur endofit adalah daun pacar (Lawsonia inermis L.) dimana tumbuhan ini banyak digunakan di Indonesia sebagai obat tradisional dan memiliki aktivitas sebagai antibakteri, anti-iritan, antioksidan, anti-karsinogenik, antiinflamasi, analgetik, dan antipiretik melalui pengujian secara in vitro dan invivo. Tumbuhan ini memilki kandungan utama senyawa aktif, seperti alkaloid, glikosida, flavonoid, fenol, saponin, tanin, dan minyak atsiri. Fenol dan flavonoid merupakan senyawa aktif yang paling banyak ditemukan.

Berdasarkan uraian di atas, penulis tertarik untuk mencari sumber penghasil senyawa bioaktif tanpa mengekstrasi tanaman yaitu dengan cara mengisolasi dan mengidentifikasi jamur endofit pada daun pacar kuku serta mengkaji metabolit sekunder yang diperoleh jamur endofit tersebut.

\section{METODE PENELITIAN}

\section{Bahan}

Bahan-bahan yang digunakan dalam penelitian ini antara lain daun pacar kuku, medium PDA, medium PDB, kloramfenikol, metanol, aquades, etanol $70 \%, \mathrm{NaOCl}$, kertas saring, kloroform, pereaksi semprot DPPH, $\mathrm{H}_{2} \mathrm{O}_{2} 3 \%$, Lieberman, dragendrof, sitro borat.

\section{Peralatan}

Alat yang digunakan dalam penelitian ini antara lain: oven, autoklaf, laminar air flow, rotary shaker, refrigerator, inkubator, mikroskop, sentrifus, lemari asam, tabung sentrifuse, timbangan digital, kompor listrik, corong, labu Erlenmeyer, gelas kimia, cawan Petri, pembakar Bunsen, gelas ukur, plastik pembungkus, aluminium foil, swab, pipet volumetrik, pinset, mikropipet, spatula, gunting, pisau steril, koran, plastik, vortex mixer, chamber, UV 366 nm, kapas, kertas label, ose, dan penggaris.

\section{Prosedur Penelitian}

\section{Isolasi Jamur Endofit}

Isolasi jamur endofit dilakukan dengan metode tanam langsung, yaitu setelah sampel dicuci aquades, direndam etanol $70 \%$ selama 30 detik, larutan $\mathrm{NaOCl}$ selama 3 menit dan perendaman terakhir menggunakan etanol $70 \%$ selama 1 menit. Selanjutnya, potongan sampel dikeringkan di atas kaca yang steril selama beberapa menit. Masing-masing sampel di potong kecil dan lapisan atas daun dikerik dengan pisau steril kemudian diletakkan di atas media PDAC (Potato Dextrosa Agar Cloramfenikol) yang telah ditambahkan dengan posisi permukaan belahan yang telah dikerik menempel pada agar médium. Sampel diletakkan di atas médium dengan diberi tekanan, dan bagian potongan berada di atas medium. Inokulasi sampel dilakukan 
di atas cawan petri dan dilakukan triplo, tiap cawan berisi 3 potongan sampel. Selama pekerjaan dilakukan di dalam laminar air flow, dan kemudian inkubasi selama 2-14 hari hari pada suhu $25-27^{\circ} \mathrm{C}$ (suhu ruang). Isolat endofit yang menunjukkan sifat morfologi jamur dipindahkan ke media PDAC yang baru.

\section{Pemurnian Jamur Endofit}

Jamur endofit yang telah tumbuh pada media isolasi PDAC, kemudian secara bertahap dimurnikan satu persatu. Masing-masing isolat murni jamur endofit yang diperoleh, kemudian dipindahkan ke dalam media dalam PDAC cawan Petri. Pemurnian ini bertujuan untuk memisahkan koloni endofit dengan morfologi berbeda untuk dijadikan isolat tersendiri. Pengamatan morfologi dilakukan kembali setelah inkubasi selama 5-7 hari, dan apabila masih ditemukan pertumbuhan koloni yang berbeda secara makroskopik maka harus dipisahkan kembali sampai diperoleh isolat murni. Jamur endofit diinkubasi pada suhu kamar selama 3-5 hari sesuai dengan pertumbuhannya. Setiap isolat murni dibuat duplo. Masingmasing sebagai kultur stok dan kultur untuk penelitian.

\section{Karakterisasi jamur endofit}

$\begin{array}{ccr} & \text { Karakterisasi } & \text { isolat jamur } \\ \text { endofit } & \text { dilakukan } & \text { dengan }\end{array}$ makroskopik dimana diamati warna dari koloni isolat jamur endofit dan secara mikroskopik langsung serta tidak langsung. Mikroskopik secara langsung dilakukan dengan cara diambil 1 ose isolat jamur endofit yang diperoleh, diigoreskan di atas object glass yang telah disterilkan kemudian difiksasi dengan pembakar spiritus. Selanjtnya ditetesi dengan 1 tetes metilen blue dan ditutup dengan cover glass dan diamati dengan mikroskop pada perbesaran 40 dan 100 kali. Mikroskop tidak langsung dilakukan dengan cara disterlikan Object glass dan cover glass dalam cawan petri dengan penyangga alumunium foil dan alat kertas saring. Diinokulasikan isolat jamur endofit ke object glass yang telah berisi 1 tetes medium PDA yang belum padat dan ditutup cover glass isolat jamur endofit. Ditetesi kertas saring dengan gliserin merata kemudian diinkubasi selama 3-5 hari selanjutnya diamati menggunakan mikroskop

\section{Fermentasi Jamur Endofit}

Fermentasi jamur endofit dilakukan dengan fermentasi cair menggunakan media PDB (Potato Dextrose Broth). Koloni murni jamur endofit pada cawan petri PDAC yang telah diinkubasi selama 5-7 hari, kemudian dengan menggunakan ose bulat diambil 3 potongan biakan jamur berukuran $\pm 1 \times 1 \mathrm{~cm}$. Potongan jamur tersebut kemudian diinokulasikan ke dalam media cair PDB sebanyak $50 \mathrm{~mL}$ dalam labu Erlenmeyer ukuran $100 \mathrm{~mL}$ dan diinkubasi 3-5 hari. Kemudian diambil $20 \mathrm{~mL}$ dan dimasukkan ke dalam Erlenmeyer yang berisi medium PDB 250 $\mathrm{mL}$ dan pecahan beling yang telah disterilkan. Selanjutnya dilakukan fermentasi goyang menggunakan rotary shaker $150 \mathrm{rpm}$ (putaran/menit) pada suhu kamar selama 14 hari. Dari masingmasing kultur yang telah difermentasi dimasukkan ke dalam tabung sentrifus ukuran $15 \mathrm{~mL}$ yang sebelumnya telah disterilisasi terlebih dahulu, kemudian di sentrifugasi dengan kecepatan $3000 \mathrm{rpm}$ selama 20 menit. Supernatan diambil dan kemudian disaring menggunakan kertas saring. Miselia yang mengendap kemudian diambil dan di keringkan di oven pada suhu $40{ }^{\circ} \mathrm{C}$ selama 3 jam dan kemudian di rendam dengan metanol selama 2 hari. Selanjutnya di saring, ekstrak miselia jamur endofit kemudian di keringkan di waterbath dan ekstrak yang diperoleh kemudian di uji.

\section{Pengujian Metabolit Sekunder}

Identifikasi metabolit sekunder pada ekstrak isolat jamur endofit 
dilakukan dengan cara Kromatografi lapis tipis (KLT) dengan eluen kloroform:metanol 5:21 dalam $1 \mathrm{~mL}$. Eluen dibuat dengan cara mengambil kloroform sebanyak $195 \mu \mathrm{L}$ dan metanol sebanyak $815 \mu \mathrm{L}$ kemudian dimasukkan ke dalam chamber dan ditunggu hingga eluen jenuh. Selanjutnya ekstrak jamur endofit di totol secara bersamaan pada plat KLT yang telah diaktifkan dengan ukuran $6 \mathrm{~cm} \times 3 \mathrm{~cm}$ yang telah diberi batas bawah $0,5 \mathrm{~cm}$ dan batas atas 0,3 $\mathrm{cm}$. Plat KLT yang telah ditotol kemudian dielusi dengan eluen yang telah dijenuhkan di dalam chamber. Selanjutnya noda diamati pada $366 \mathrm{~nm}$ dan disemprot dengan pereaksi semprot sitro borat dan timbal asetat untuk uji flavonoid, pereaksi Lieberman untuk uji triterpen, pereaksi dragendrof untuk uji alkaloid, pereaksi $\mathrm{H}_{2} \mathrm{O}_{2}$ untuk uji asam aromatis, pereaksi asam fosfat $85 \%$ untuk uji steroid. Kemudian ekstrak isolat jamur juga diuji aktivitas antioksidan secara kualitatif dengan metode DPPH semprot dimana positif apabila noda berubah menjadi kuning dengan latar ungu.

\section{HASIL DAN PEMBAHASAN}

\section{Isolat Jamur Endofit dari Lawsonia inermis $\mathbf{L}$.}

Jumlah isolat jamur endofit yang telah berhasil diisolasi dari bagian daun Lawsonia inermis L berjumlah 3 isolat. Sebelum jamur endofit diisolasi dari inangnya, permukaan daun pacar harus disterilkan terlebih dahulu. Daun pacar yang akan digunakan, sebaiknya dipilih yaitu daun yang tidak terlalu tua dan juga bukan daun yang terletak di pucuk. Selanjutnya, daun pacar dicuci dengan air mengalir, kemudian di rendam dengan alkohol $70 \%$ selama 30 detik untuk menhilangkan lapisan minyak atau lemak di permukaan daun. Setelah itu, daun pacar di rendam di larutan $\mathrm{NaOCl}$ selama 3 menit. Kemudian langkah terakhir, daun pacar di rendam kembali pada alkohol $70 \quad \%$ selama 1 menit untuk membersihkan daun dari rendaman $\mathrm{NaOCl}$. Daun pacar yang telah disterilkan yang telah dikerik lapisan atasnya kemudian dipotong kecil-kecil dan kemudian di letakkan di atas medium PDAC (Potato Dextrosa Agar Cloramfenikol) yang telah memadat selanjutnya diinkubasi 7-14 pada suhu ruang. Pengamatan dilakukan pada hari ke 3 hingga hari ke 14, dimana diamati pertumbuhan jamur yang tumbuh diatas daun pacar. Jamur yang diperoleh kemudian di inokulasikan ke medium PDAC dan diinkubasi 3-5 hari untuk mendapatkan isolat murni jamur endofit dengan karakteristik persamaan warna dan bentuk koloni. Fungsi kloramfenikol yang di tambahkan pada medium PDA ditujukan untuk menghambat pertumbuhan bakteri endofit atau bakteri kontaminan yang mungkin dapat mengkontaminasi. Isolat jamur endofit yang dihasilkan dari tumbuhan inang dapat menghasilkan jenis isolat yang berbeda-beda dengan jumlah yang bervariasi. Menurut Noverita pada artikelnya hal ini merupakan mekanisme adaptasi dari endofit terhadap mikroekologi dan kondisi fisiologis yang spesifik dari masing-masing tumbuhan inang $^{2}$. Bahkan dari satu jaringan hidup suatu tumbuhan dapat diisolasi lebih dari 1 jenis jamur endofit. Menurut Petrini dkk., bahwa kehadiran jenis endofit dihubungkan dengan kondisi mikrohabitat tanaman inang dan kecocokan genotip antara tanaman inang dan endofit, sehingga akan berpengaruh terhadap perbedaan dalam komposisi koloni endofit dan tingkat infeksi tanaman inang yang di tempati oleh jamur endofit pada lokasi yang sama.

Hasil isolat jamur endofit dari teknik isolasi selanjutnya dilakukan pengamatan secara makroskopis dan mikroskopis dimana masing-masing memiliki karakteristik yang berbeda-beda (gambar 1). 
Pengamatan mikroskopik tidak
langsung dilakukan dengan menginokulasikan jamur endofit ke atas media PDAC yang telah diteteskan di atas object glass yang disangga oleh batang berbentuk $\mathrm{V}$ dan kemudian ditutup cover glass. Selanjutnya di sekitar object glass di tetesi gliserin dengan tujuan membuat suasana lembab. Kemudian setelah diinkubasi $7 \times 24$ jam diinkubasi, diamati dengan mikroskop (gambar 2).

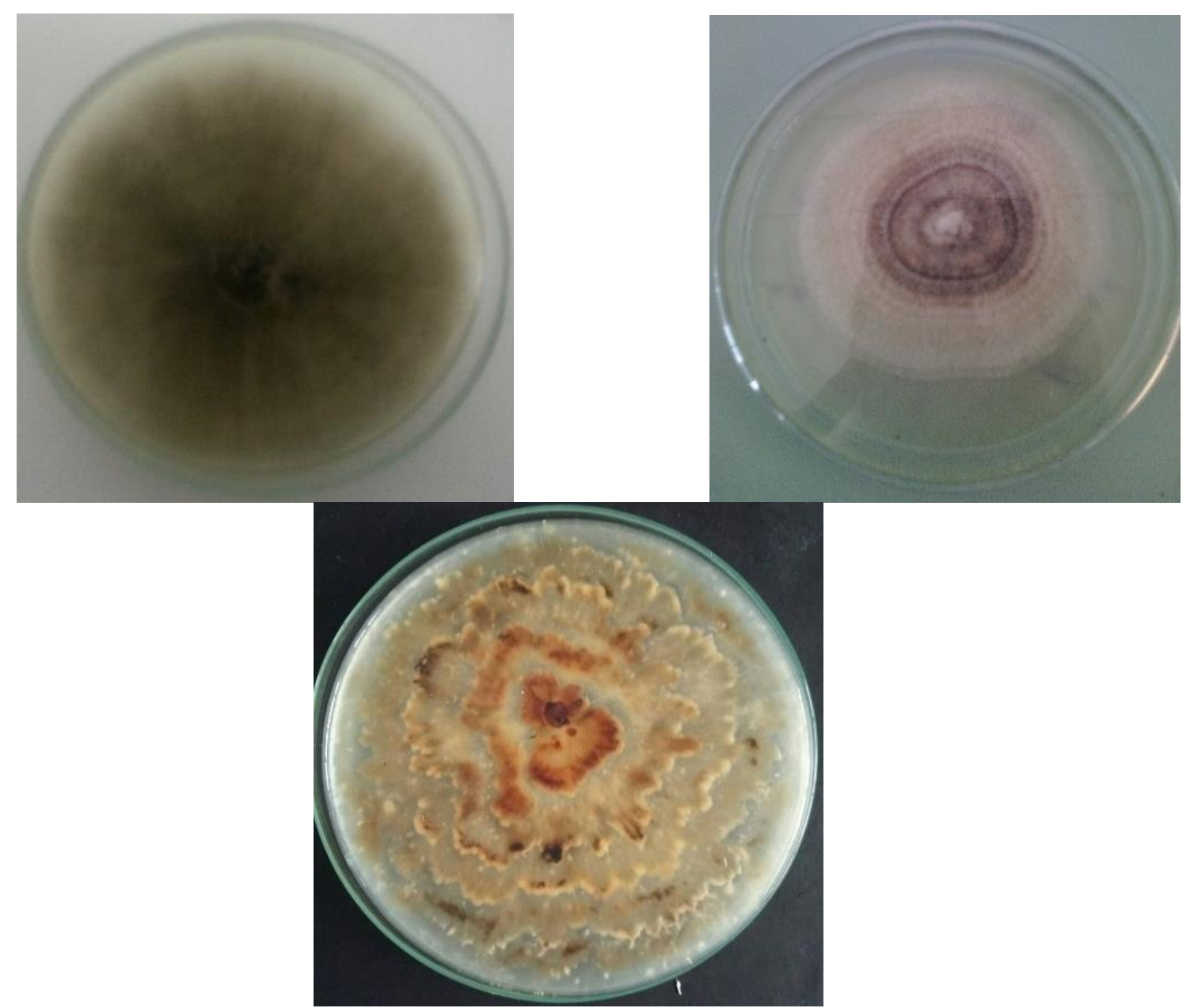

Gambar 1. koloni isolat jamur endofit dari daun pacar kuku (hitam serabut, putih kuning, putih melingkar)

Tabel 1. Hasil pengamatan makroskopik isolat jamur endofit

\begin{tabular}{lll}
\hline \multicolumn{1}{c}{ Isolat } & \multicolumn{1}{c}{ Warna permukaan koloni } & \multicolumn{1}{c}{ Bentuk koloni } \\
\hline Isolat jamur putih kuning & Kuning tua dengan pinggiran putih & Tidak berserabut \\
Isolat jamur putih melingkar & Hitam dengan serabut putih yang melingkar & Berserabut \\
Isolat hitam berserabut & Hitam & Berserabut \\
\hline
\end{tabular}




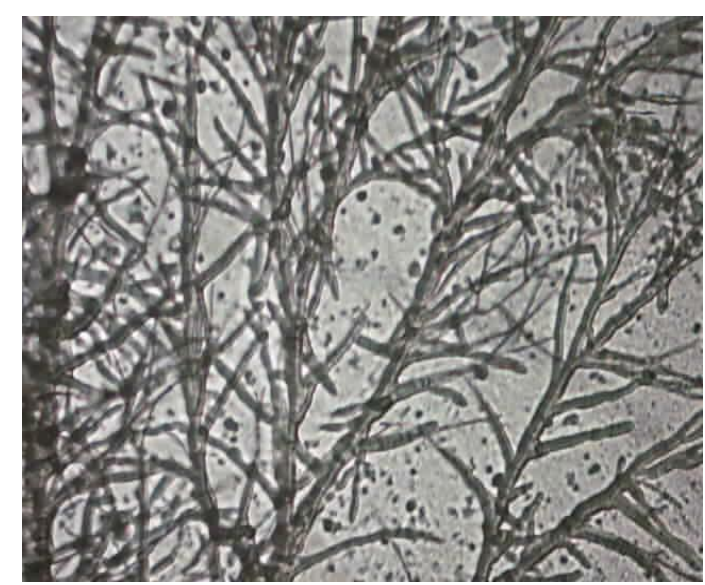

2.1. koloni jamur hitam

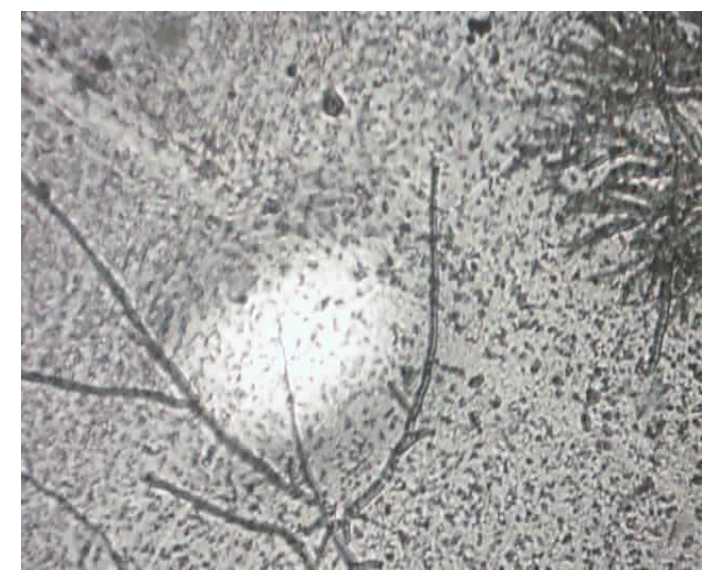

2.3. koloni putih kuning

\section{Produksi Metabolit sekunder jamur endofit dan aktivitas antioksidan dengan metode DPPH semprot}

Metabolit sekunder yang diuji pada penelitian ini adalah golongan flavonoid, asam aromatis, steroid, alkaloid, dan triterpen serta uji aktivitas antioksidan secara kualitatif dengan metode DPPH semprot.

Jamur endofit merupakan jamur yang tumbuh dalam jaringan tumbuhan yang mampu membentuk koloni dalam jaringan tanaman tanpa membahayakan tanaman inangnya. Menurut Mikhaeil tahun 2004 pengujian pada ekstrak metanol daun Lawsonia inermis $\mathrm{L}$ melalui pola fraksinasi menghasilkan tujuh golongan senyawa, yakni asam $p$ -

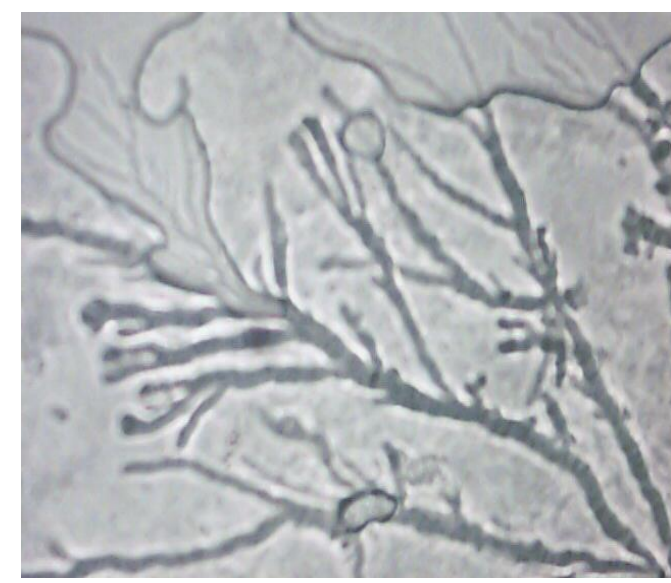

2.2. koloni putih

coumaric, 2-methoxy-3-methyl-1,4naphthoquinone, apiin, lawsone, apigenin, luteolin, dan cosmosiin. Semua golongan senyawa yang diisolasi ini memperlihatkan aktivitas antioksidan yang dapat dibandingkan dengan asam ascorbic.

Kandungan metabolit sekunder yang terdapat pada tanaman daun pacar dan aktivitas antioksidannya menjadi acuan untuk meneliti macam kandungan yang dimiliki oleh isolat jamur endofit yang berasal dari daun pacar kuku. Menurut Radji pada tahun 2005, jamur endofit mampu menghsilkan metabolit sekunder yang sama dengan inangya. Hal ini disebabkan oleh transfer genetik akibat koevolusi antara jamur endofit dan tanaman inangnya. 
Uji flavonoid pada penelitian ini menggunakan pereaksi semprot sitro borat dan timbal asetat dengan hasil positif. Warna fluoresensi yang terbentuk adalah fluoresensi kuning atau kuning kehijauan dengan sinar UV $366 \mathrm{~nm}$. Sitroborat sebagai pereaksi flavonoid hanya berlaku jika flavonoid tersebut memiliki gugus o-dihidroksi bebas. Uji golongan asam aromatis menggunakan pereaksi hidrogen peroksida dimana hasil positif pada ekstrak dari isolat hitam dan putih kuning yang ditunjukkan dengan noda berpendar biru pada UV $366 \mathrm{~nm}$. Uji golongan trterpen dilakukan dengan pereaksi semprot lieberman burchad dan hasil positif pada ke 3 noda yang ditunjukkan noda berpendar pada UV 366 nm. Selanjutnya pada uji alkaloid hasil negatif pada ke 3 ekstrak isolat jamur endofit. Pada uji steroid dengan reaksi semprot asam fosfat, hasil positif pada ke 3 noda yang ditunjukkan noda berpendar pada UV $366 \mathrm{~nm}$.

Tabel 2. Hasil metabolit sekunder ekstrak isolat jamur endofit

\begin{tabular}{ccccc}
\hline \multirow{2}{*}{ Uji } & Pereaksi & \multicolumn{3}{c}{ Hasil } \\
\cline { 2 - 5 } & Sitro borat & + & + & + \\
Flavonoid & $\mathrm{H}_{2} \mathrm{O}_{2}$ & - & + & + \\
Asam aromatis & Asam Fosfat & + & + & + \\
Triterpen & Dragendrof & - & - & - \\
Alkaloid & Lieberman & + & + & + \\
Steroid & Timbal asetat & + & + & + \\
Flavonoid & DPPH & + & + & + \\
Antioksidan & & & &
\end{tabular}

Keterangan: $(+)=$ mengandung

$(-)=$ tidak mengandung

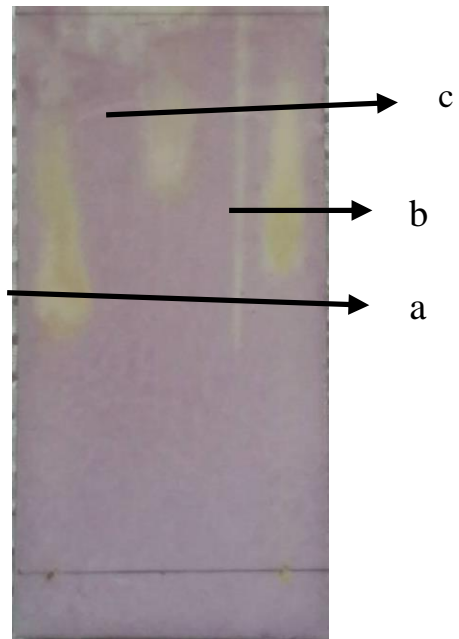

Gambar 3. Uji antioksidan ekstrak isolat putih (a), putih kuning (b), hitam (c)

Selanjutnya dilakukan uji antioksidan secara kualitatif dimana noda yang telah dielusi kemudian di semprot dengan DPPH 4 ppm. Hasil yang diperoleh dari ke 3 ekstrak adalah positif antioksidan dimana noda berubah warna kuning dengan latar ungu (gambar 3). Mekanisme antioksidan Flavonoid dalam ekstrak etanol daun dewa akan melepaskan $\mathrm{H}$ - yang merupakan salah satu radikal bebas. $\mathrm{H}$. akan berikatan dengan radikal DPPH membentuk 
senyawa baru yaitu difenil pikrilhidrazin yang stabil. Senyawa flavonoid yang terkandung dalam ekstrak etanol daun dewa sebagai penangkap radikal bebas yang kehilangan $\mathrm{H}$. akan menjadi radikal baru yang relatif lebih stabil dan tidak berbahaya bagi tubuh karena adanya efek resonansi inti aromatik.

\section{KESIMPULAN DAN SARAN}

Berdasarkan hasil penelitian yang dilakukan dapat diambil kesimpulan sebagai berikut :

1. Dari daun pacar (Lawsonia inermis L.) dapat diperoleh 3 isolat jamur endofit.

2. Ketiga isolat jamur endofit tersebut memiliki sifat antioksidan terhadap DPPH

3. Metabolit sekunder yang dihasilkan dari ekstak isolat jamur endofit putih adalah golongan flavonoid, steroid, triterpenoid. Ekstrak isolat jamur kuning dan hitam menghasilkan metabolit sekunder golongan flavonoid, steroid, asam aromatis, triterpenoid.

\section{DAFTAR PUSTAKA}

1. Petrini O, Sieber TN, Toti L, dan Viret O. 1992. Ecology metabolite production and substrate utilization in endophytic fungi. Natural Toxins vol 1:185-196.

2. Noverita. 2009. Isolasi Dan Uji Aktivitas Antibakteri Jamur Endofit Dari Daun Dan Rimpang Zingiber ottensi Val. Jurnal Farmasi Indonesia Vol. 4 No. 4

3. Mikhaeil BR, Badria FA, Maatooq GT, Amer MM. 2004. Antioxidant and Immunomodulatory Constituent of Henna Leaves. Z Naturforsch [C]; 59(7-8):468-76.

4. Radji, M. 2008. Peranan Bioteknologi dan Mikroba Endofit dalam Pengembangan Obat Herbal. Laboratorium Mikrobiologi dan Bioteknologi. Vol. II. Departemen Farmasi, FMIPA-UI, Kampus UI Depok. 113 - 126. Departemen Farmasi, FMIPA-UI, Kampus UI Depok 16424 Majalah Ilmu Kefarmasian, No.3, 113 - 126

5. Widyaningsih Wahyu. 2010. Uji Aktivitas Antioksidan Ekstrak Etanol Daun Dewa (Gynura procumbens) Dengan Metode DPPH (1,1-difenil-2pkrilhidrazil). Fakultas Farmasi Ahmad Dahlan, Yogyakarta 